\title{
Species identification and antimicrobial susceptibility profile of bacteria associated with cow mastitis in southern Brazil ${ }^{1}$
}

\author{
Tamiris S. Lopes ${ }^{2}$, Caroline Fussieger ${ }^{2}$, Fábio Antunes Rizzo ${ }^{2}$, Simone Silveira ${ }^{3}$, \\ Vagner Ricardo Lunge ${ }^{2}$ and André Felipe Streck ${ }^{2 *}$ (D)
}

\begin{abstract}
Lopes T.S., Fussieger C., Rizzo F.A., Silveira S., Lunge V.R. \& Streck A.F. 2022. Species identification and antimicrobial susceptibily profile of bacteria associated with cow mastitis in southern Brazil. Pesquisa Veterinária Brasileira 42:e06958, 2022. Laboratório de Diagnóstico em Medicina Veterinária, Universidade de Caxias do Sul, Rua Francisco Getúlio Vargas 1130, Campus-Sede, Caxias do Sul, RS 95070-560, Brazil. E-mail: afstreck@ucs.br

Bovine mastitis is the most common disease in dairy cattle and responsible for economic losses in the milk industry. The present study aimed to identify the main species and to evaluate the antimicrobial susceptibility of bacterial isolates from cow herds with mastitis in dairy farms from southern Brazil. A total of 107 milk samples were collected from different cow herds in one important dairy producing region in southern Brazil, including farms located in ten cities from the Northeast region in the Rio Grande do Sul state. Bacterial strains were isolated and submitted to presumptive identification by classical bacteriological methods. Bacterial species were also identified by MALDI-TOF MS and antimicrobial susceptibility testing was performed with 12 antimicrobials commonly used in dairy farms. Fifty-one bacterial strains were isolated and the presumptive identification demonstrated the occurrence of Staphylococcus spp. (82.3\%), Bacillus spp. (3.9\%), Klebsiella spp. (3.9\%), Streptococcus spp. (3.9\%), Corynebacterium sp. (2\%), Enterococcus sp. (2\%) and Serratia sp. (2\%). Forty-one isolates were successfully identified in the MALDI-TOF analysis, including 35 isolates from eleven different bacterial species. Importantly, there were eight different Staphylococcus species, with a high frequency of Staphylococcus chromogenes (48.6\%) and Staphylococcus aureus (20\%). Overall, bacterial isolates demonstrated resistance to penicillin (46.3\%), tetracycline (39\%), amoxicillin (36.6\%), ampicillin (34.1\%) and sulfamethoxazole/trimethoprim (31.7\%). Enrofloxacin was the unique antimicrobial that all isolates were susceptible. In addition, there were six multidrug resistant isolates (five $S$. chromogenes and one $S$. aureus). This study highlights that bacterial pathogens with resistance to several antimicrobials were identified in cows from dairy farms in a very important milk producing region located in southern Brazil. Microbial identification of the bovine mastitis pathogens and determination of the antimicrobial profile is necessary for the rational use of the medicines.
\end{abstract}

INDEX TERMS: Species identification, antimicrobial resistance, mastitis, milk, Staphylococcus, MALDITOF MS, public health, cattle, Brazil.

RESUMO.- [Identificação de espécies e perfil de suscetibilidade aos antimicrobianos de bactérias associadas à mastite bovina no sul do Brasil.] A mastite bovina é a

\footnotetext{
${ }^{1}$ Received on October 15, 2021.

Accepted for publication on October 31, 2021.

${ }^{2}$ Laboratório de Diagnóstico em Medicina Veterinária, Universidade de Caxias do Sul (UCS), Rua Francisco Getúlio Vargas 1130, Campus Sede, Caxias do Sul, RS 95070-560, Brazil. *Corresponding author: afstreck@ucs.br

${ }^{3}$ Laboratório de Imunodiagnóstico, Universidade do Oeste de Santa Catarina (UNOESC), Rodovia Rovilho Bortoluzzi SC-480, Barro Preto, Xanxerê, SC 89820-000, Brazil.
}

doença mais comum em gado leiteiro e responsável por perdas econômicas na indústria de laticínios. 0 presente estudo teve como objetivo identificar as principais espécies e avaliar a suscetibilidade antimicrobiana de isolados bacterianos de rebanhos bovinos com mastite em fazendas leiteiras no sul do Brasil. Um total de 107 amostras de leite foram coletadas em diferentes rebanhos bovinos em uma importante região produtora de leite do sul do Brasil, incluindo fazendas localizadas em 10 cidades da região Nordeste do estado do Rio Grande do Sul. As cepas bacterianas foram isoladas e submetidas à identificação presuntiva por métodos bacteriológicos clássicos. 
A identificação bacteriana foi confirmada por MALDI-TOF MS e o teste de sensibilidade antimicrobiana foi realizado com antimicrobianos comumente usados em fazendas leiteiras. Cinquenta e uma cepas bacterianas foram isoladas e a identificação presuntiva demonstrou a ocorrência de Staphylococcus spp. (82,3\%), Bacillus spp. (3,9\%), Klebsiella spp. $(3,9 \%)$, Streptococcus spp. $(3,9 \%)$, Corynebacterium sp. (2\%), Enterococcus sp. (2\%) e Serratia sp. (2\%). Os 41 isolados foram identificados com sucesso na análise MALDITOF, incluindo 35 isolados de onze espécies bacterianas diferentes. É importante ressaltar que houve a ocorrência de oito espécies diferentes de Staphylococcus, com alta frequência de Staphylococcus chromogenes (48,6\%) e Staphylococcus aureus (20\%). No geral, os isolados bacterianos tiveram alta resistência à penicilina $(46,3 \%)$, tetraciclina $(39 \%)$, amoxicilina $(36,6 \%)$, ampicilina $(34,1 \%)$ e sulfametoxazol/trimetoprima $(31,7 \%)$. A enrofloxacina foi o único antimicrobiano que todos os isolados foram suscetíveis. Além disso, havia seis isolados multirresistentes (cinco S. chromogenes e um S. aureus). Este estudo destaca que os patógenos bacterianos com resistência aos antimicrobianos estão presentes em fazendas leiteiras de subsistência em uma importante região produtora no sul do Brasil. É necessário o monitoramento constante dos patógenos da mastite bovina e a determinação de seu perfil antimicrobiano para o uso racional dos medicamentos.

TERMOS DE INDEXAÇÃO: Identificação de espécies, resistência antimicrobiana, mastite, leite, Staphylococcus, MALDI-TOF MS, saúde pública, bovinos, Brasil.

\section{INTRODUCTION}

Brazil has the second largest dairy herd in the world and bovine mastitis is one of the main health problems affecting herds, with important economic losses in all dairy supply chain (Duarte et al. 2020). This disease is characterized by an inflammation of the mammary gland, which directly affects its physiological function and cause symptoms such as: changes in color and consistency of milk, udder alterations, systemic disease and decreased yield (Kibebew 2017, Braga et al. 2018).

Mastits usually occurs as a consequence of bacterial infections (Haubert et al. 2017). More than 130 bacterial species have already been associated with bovine mastitis (Holko et al. 2019). However, few bacterial species (Staphylococcus aureus, Streptococcus uberis, Streptococcus dysgalactiae and Escherichia coli) are responsible for approximately $80 \%$ of the mastitis cases (Braga et al. 2018). Other coagulase-positive Staphylococcus (CPS) and coagulase-negative staphylococci (CNS) have also been frequently associated with mastitis (Blaiotta et al. 2010, Vanderhaeghen et al. 2014, Haubert et al. 2017).

The therapeutic scheme for the prevention and treatment of cow mastitis cases is generally based on the administration of antimicrobials (Ruegg 2017, Zhang et al. 2018). The large use of these medicines has resulted in a high increase of the antimicrobial resistance in different bacterial species isolated from milk samples in Brazil (Mesquita et al. 2019). Importantly, many bacterial isolates have already presented resistance to three or more antimicrobial classes, evidencing the occurrence of multidrug-resistance (MDR) (Machado et al. 2008, Silva et al. 2012, Valmorbida et al. 2017, Dorneles et al. 2018, Freitas et al. 2018).
In southern Brazil, small dairy farms based on family labor are very important to produce milk for the processing industries. One important challenge in these farms is the lack of technical assistance, leading to failures in animal management to prevent intramammary infections resulting in bovine mastitis, which the treatment is usually performed without technical guidance (Girardini et al. 2016). These practices may increase the risk of antimicrobial resistance and resistant bacterial strains can spread to the community by direct contact with infected animals or eating contaminated animal products (Dorneles et al. 2018).

The aim of this study was to identify the bacterial species as well as to characterize antimicrobial susceptibility from milk samples isolates of cows with mastitis in small dairy farms from southern Brazil.

\section{MATERIALS AND METHODS}

Dairy farms and sample collection. Cows with a history of recurrent mastitis were chosen for this study. These animals were from farms located in one important dairy region in South Brazil (the Northeast from the Rio Grande do Sul state), including ten counties: Anta Gorda, Caxias do Sul, Estrela, Farroupilha, Gramado, Nova Araçá, Nova Bassano, Nova Petrópolis, Paraí and São Jorge (Fig.1). Milk samples were collected by veterinarians between March and July 2019. Briefly, selected teats presenting visible milk alterations or positive result in the California Mastitis Test (CMT) were washed and dried with a paper towel and disinfected with alcohol (70\%) (NMC 2004). Three streams of milk were collected in sterile tubes, immediately frozen and sent to the diagnostic laboratory ("Laboratório de Diagnóstico em Medicina Veterinária") in the "Universidade de Caxias do Sul" (UCS), Caxias do Sul, Brazil. This study was approved by the Ethical Committee on the Use of Animals of UCS (number 12/2018).

Bacteriological culture. Bacterial culture was performed according to the guidelines described by the National Mastitis Council (NMC 2004). A total of $10 \mu \mathrm{L}$ of each milk sample was plated in Columbia agar with $5 \%$ sheep blood and MacConkey agar (Kasvi ${ }^{\circledR}$, São José dos Pinhais/PR, Brazil). The plates were incubated aerobically at $37 \pm 1^{\circ} \mathrm{C}$ for 24 to $72 \mathrm{~h}$. The samples were considered positive when one or more colonies were observed ( $\geq 100 \mathrm{CFU} /$ $\mathrm{mL}$ ) (Verbeke et al. 2014). When three or more different colonies types were identified in the agar plate, contamination was assumed and results disregarded (NMC 2004). Presumptive identification of bacterial species was firstly performed by traditional bacteriological procedures according to previously described (Verbeke et al. 2014). Briefly, colonies were identified by morphological appearance and Gram staining. Hemolysis evaluation and catalase activity were performed on Gram-positive cocci. Presumptive Staphylococcus spp. isolates were analyzed for coagulase activity. Presumptive Enterococcus spp. and Streptococcus spp. were further differentiated based on bile esculin test and incubation on BHI medium with 6.5\% of $\mathrm{NaCl}$ (Kasvi ${ }^{\circledR}$, Brazil). Corynebacterium spp. was identified by urea production and oxidation/fermentation tests. Bacillus spp. was identified by characteristic morphology of the colonies. Gramnegative bacilli were identified by the following biochemical tests: lactose fermentation, motility, indole production, $\mathrm{H}_{2} \mathrm{~S}$ production, triple sugar iron, utilization of citrate and lysine decarboxylation. All isolates were stored in skim milk with glycerol at $-80^{\circ} \mathrm{C}$.

MALDI-TOF MS. Matrix-assisted laser desorption/ionization time-of-flight mass spectrometry (MALDI-TOF MS) was carried out as previously described (Braga et al. 2018). The software Biotyper 4.0 was utilized for the identification of bacterial species. A log score 
$\geq 2$ ensures safe identification in genus and species. Scores between 2-1.7 assure safe identification for genus level and probable for species level. Finally, scores $\leq 1.69$ were considered insufficient for identification at any taxonomic level.

Antimicrobial susceptibility test. Determination of antimicrobial susceptibility was performed using the Kirby-Bauer disc diffusion method (Bauer et al. 1966, CLSI 2020). Twelve antimicrobials commonly used in the treatment of cow mastitis in southern Brazil were evaluated: amoxicillin/clavulanic acid $30 \mu \mathrm{g}$, amoxicillin $10 \mu \mathrm{g}$, ampicillin $10 \mu \mathrm{g}$, cefalexin $30 \mu \mathrm{g}$, ceftiofur $30 \mu \mathrm{g}$, ceftriaxone $30 \mu \mathrm{g}$, enrofloxacin $5 \mu \mathrm{g}$, gentamicin $10 \mu \mathrm{g}$, neomycin $30 \mu \mathrm{g}$, penicillin G $6 \mu \mathrm{g}$, sulfamethoxazole/trimethoprim $25 \mu \mathrm{g}$ and tetracycline $30 \mu \mathrm{g}$ (Cefar, São Paulo/SP, Brazil). Isolates were categorized into susceptible, intermediate or resistant and multidrug resistance (MDR) was assumed when the isolate was resistant to three or more antimicrobials classes (CLSI 2020).

\section{RESULTS}

\section{Mastitis etiology}

A total of 107 milk samples were obtained from different dairy farms located in ten municipalities: Nova Petrópolis $(\mathrm{n}=59)$, Caxias do Sul $(\mathrm{n}=18)$, Estrela $(\mathrm{n}=11)$, Nova Bassano $(n=4)$, Farroupilha $(n=3)$, São Jorge $(n=3)$, Paraí $(n=3)$, Gramado $(\mathrm{n}=2)$, Nova Araçá $(\mathrm{n}=2)$ and Anta Gorda $(\mathrm{n}=2)$. Overall, 85 were individual quarter samples and 22 were mixed samples (mixes of 2 to 4 quarters from the same cow). After bacteriological culture, 56 samples were discarded because the absence of colony growth or any evidence of bacteriological contamination. The remaining 51 isolates from different milk samples were identified with bacteriological methods.

The results of the presumptive identification of the bacterial genus are presented in Table 1 . The initial identification of bacterial isolates indicated the occurrence of Gram-positive cocci $(n=45)$, followed by Gram-negative bacilli $(n=3)$ and Gram-positive bacilli ( $\mathrm{n}=3$ ). Staphylococcus spp. were further classified into CPS (n=9) and CNS (n=33).

Table 1. Bacteria genus obtained from milk sample from cows with diagnosis of mastitis in dairy farms in southern Brazil

\begin{tabular}{lccc}
\hline \multicolumn{1}{c}{ Presumptive identification } & Morphology & Gram stain & N (\%) \\
\hline Staphylococcus spp. & Cocci & Positive & $42(82.3)$ \\
Klebsiella spp. & Bacilli & Negative & $2(3.9)$ \\
Streptococcus spp. & Cocci & Positive & $2(3.9)$ \\
Bacillus spp. & Bacilli & Positive & $2(3.9)$ \\
Serratia sp. & Bacilli & Negative & $1(2.0)$ \\
Enterococcus spp. & Cocci & Positive & $1(2.0)$ \\
Corynebacterium spp. & Bacilli & Positive & $1(2.0)$ \\
TOTAL & - & - & $51(100.0)$
\end{tabular}

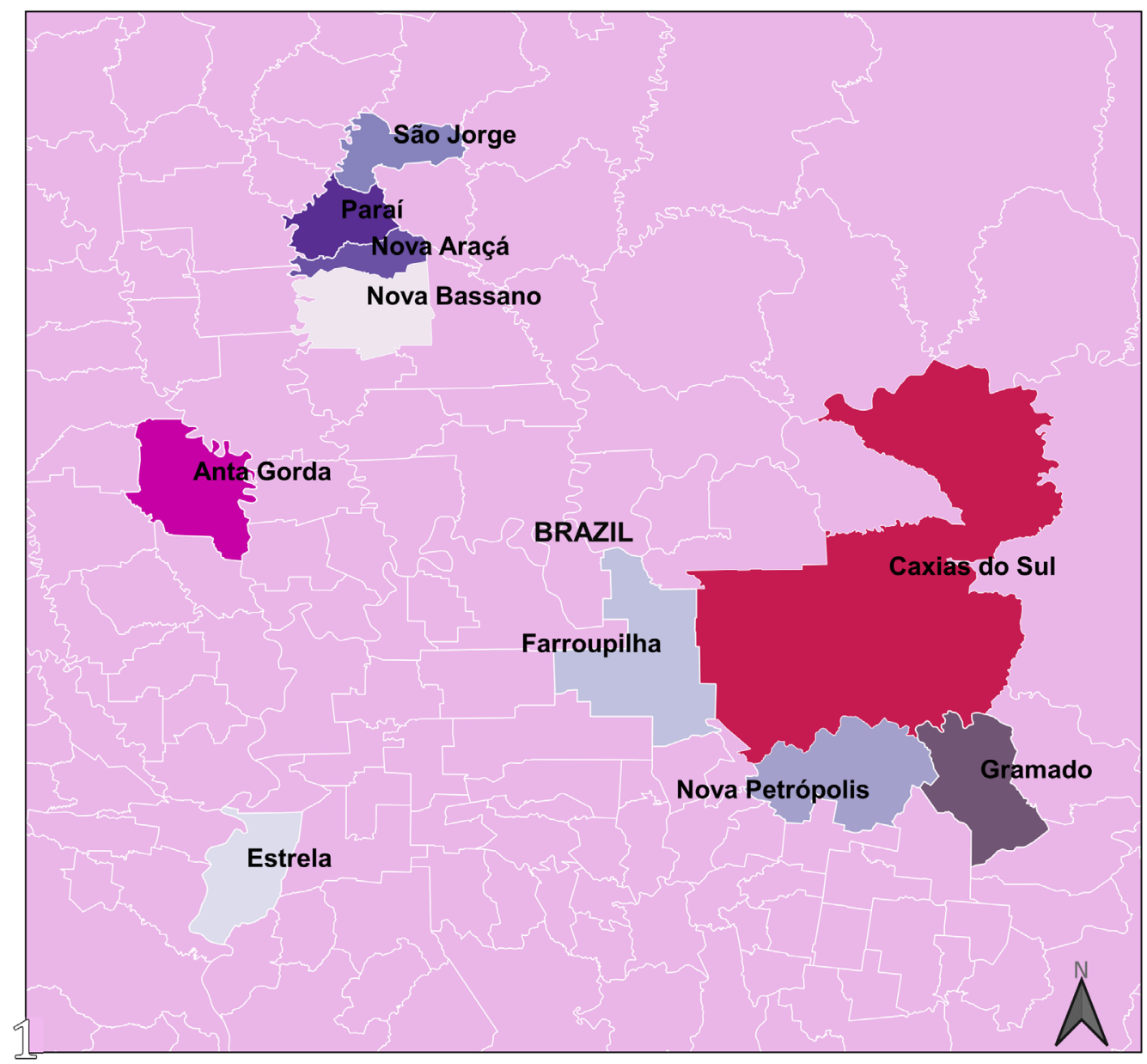

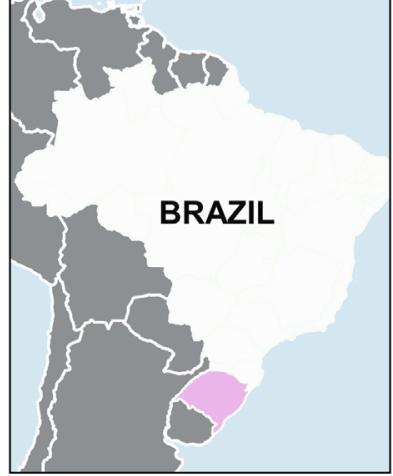

MAP ELEMENTS

Milk collection cities

Caxias do Sul

Nova Bassano

Estrela

Farroupilha

Nova Petrópolis

São Jorge

Nova Araçá

Paraí

Anta Gorda

Gramado

State

RS: Rio Grande do Sul

0

20

$40 \mathrm{~km}$

Fig.1. Map indicating the ten cities where milk collections were carried out, in the state of Rio Grande do Sul, Brazil. 


\section{Bacterial species}

MALDI-TOF MS coupled to the Biotyper version 4.0 was used to analyze all the 51 isolates. A total of 41 isolates were identified with good accuracy. It was observed the predominance of Staphylococcus spp. ( $\mathrm{n}=35,85.4 \%)$, but Klebsiella spp. $(\mathrm{n}=2$, $4.9 \%)$, Streptococcus spp. ( $\mathrm{n}=2,4.9 \%)$, Serratia sp. $(\mathrm{n}=1,2.4 \%)$ and Enterococcus sp. (n=1, 2.4\%) were also identified in the samples. The remaining ten isolates (19.6\%) presented low analytical scores, insufficient for a safe bacterial identification. According to the presumptive identification of these isolates, there were seven (70\%) Staphylococcus spp., two (20\%) Bacillus spp. and one (10\%) Corynebacterium sp.

Among the 35 isolates from the genus Staphylococcus, eight different bacterial species were identified: Staphylococcus chromogenes $(\mathrm{n}=17,48.6 \%)$, Staphylococcus aureus $(\mathrm{n}=7$, $20 \%)$, Staphylococcus epidermidis ( $\mathrm{n}=3,8.6 \%)$, Staphylococcus xylosus $(\mathrm{n}=3,8.6 \%)$, Staphylococcus sciuri $(\mathrm{n}=2,5.8 \%)$,
Staphylococcus haemolyticus $(\mathrm{n}=1,2.8 \%)$, Staphylococcus pseudintermedius $(\mathrm{n}=1,2.8 \%)$ and Staphylococcus warneri $(\mathrm{n}=1,2.8 \%)$. CNS were more frequent isolated $(\mathrm{n}=27,77.1 \%$; including S. chromogenes, S. epidermidis, S. xylosus, S. sciuri, $S$. haemolyticus and $S$. warneri) than CPS (n=8, 22.9\%; including $S$. aureus and $S$. pseudintermedius).

In the remaining six isolates from other bacterial genera, four species were identified: two Klebsiella varilicola, two Streptococcus uberis, one Enterococcus faecalis and one Serratia marcescens (Fig.2).

\section{Antimicrobial susceptibility test}

Thirteen isolates (31.7\%) were susceptible to all evaluated antimicrobials. The antimicrobial profile of the remaining 28 $(68.3 \%)$ isolates demonstrated resistance to one $(n=7)$, two $(n=4)$, three $(n=8)$, four $(n=2)$, five $(n=3)$, six $(n=2)$ and even seven $(n=2)$ different antimicrobials (Fig.2). Importantly,

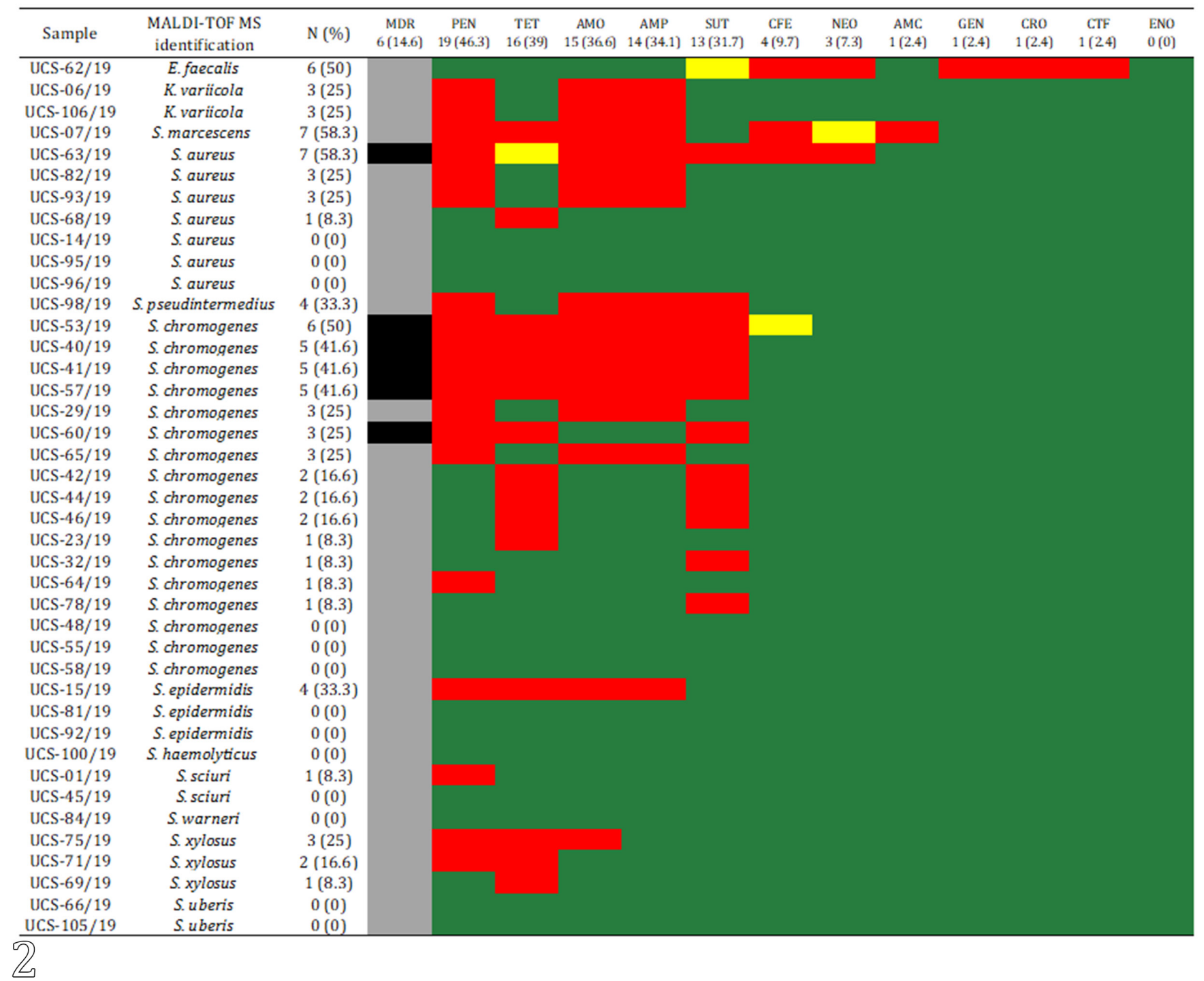

Fig.2. Antimicrobial susceptibility profile of isolates from mastitis cases in southern Brazil. Black = multidrug resistance (MDR) isolates, Gray = non MDR resistance. Green = susceptible, Red = resistant, Yellow = intermediate resistance. $\mathrm{N}$ is the number of antimicrobials with resistance, followed by percentage (intermediate resistance was included). Penicillin (PEN), tetracycline (TET), amoxicillin (AMO), ampicillin (AMP), sulfamethoxazole/trimethoprim (SUT), cefalexin (CFE), neomycin (NEO), amoxicillin/clavulanic acid (AMC), gentamicin (GEN), ceftriaxone (CRO), ceftiofur (CTF), enrofloxacin (ENO). 
bacterial isolates of the genus Staphylococcus were usually resistant from one to seven different antimicrobials $(n=24$, $68.6 \%$ ). Furthermore, six isolates (five $S$. chromogenes and one S. aureus) were additionally classified as multidrug resistant (MDR). Overall, S. chromogenes presented a higher number of MDR isolates $(\mathrm{n}=5)$ than $S$. aureus $(\mathrm{n}=1)$. The unique isolates of $S$. marcescens and E. faecalis also demonstrated resistance to several antimicrobials (7 and 6, respectively) (Fig.2).

The number and frequency of resistance was high to penicillin $(n=19,46.3 \%)$, tetracycline $(n=16,39 \%)$, amoxicillin $(n=15,36.6 \%)$, ampicillin $(n=14,34.1 \%)$ and sulfamethoxazole/trimethoprim $(n=13,31.7 \%)$. All of the remaining antimicrobials were effective in inhibiting the growth of most isolates. Noteworthy, enrofloxacin was the unique antimicrobial that all isolates were susceptible. The analysis according to the antimicrobial class demonstrated a higher frequency of resistance to $\beta$-lactams $(46.3 \%)$, followed by tetracyclines (39\%) and sulfonamides $(31.7 \%)$. The resistance was below than $10 \%$ for cephalosporins and aminoglycosides class, and all strains were susceptible to the unique evaluated fluoroquinolone (enrofloxacin).

\section{DISCUSSION}

In the present study, 107 milk samples were collected in dairy farms from an important milk production region in southern Brazil. These farms did not have well-established prevention protocols against contagious or environmental mastitis, and the cows sampled had repeated episodes of mastitis. The properties carry out basic hygiene measures during milking routine and cases of chronic mastitis are often treated with antibiotic dry cow therapy. However, the selection of these antibiotics are often empirical in small dairy farms.

According the bacteriological culture, 51 isolates were first presumptively identified and the results demonstrated the predominance of the genus Staphylococcus $(82.3 \%)$. Characterization by MALDI-TOF MS showed that they were CNS and CPS. Staphylococcus spp. was also the most commonly bacterial genus isolated from bovine mastitis in previous studies carried out in Brazil (Oliveira et al. 2011, Haubert et al. 2017, Valmorbida et al. 2017, Lavor et al. 2019) and even in other countries (Sztachańska et al. 2016, Vakkamäki et al. 2017, Kim et al. 2019). On contrast, 56 milk samples dit not present bacterial growth. Culture-negative samples may be explained by the real absence of any bacteria as well as the occurrence of intermittent elimination of some bacteria, including Staphylococcus aureus (Barkema et al. 2006).

Most staphylococci identified in the present study were CNS, including six species: Staphylococcus chromogenes, Staphylococcus epidermidis, Staphylococcus xylosus, Staphylococcus sciuri, Staphylococcus haemolyticus and Staphylococcus warneri. S. chromogenes was the most widespread CNS species as also observed in other studies performed in Brazil (Tomazi etal. 2014, Braga et al. 2018). CNS was firstly considered as opportunistic pathogens of minor clinical importance (Schmidt et al. 2015), but they are frequently being detected in bovine mastitis in the last years (Freitas et al. 2018). Specifically, S. chromogenes and S. xylosus can cause an important inflammatory process affecting udder health (Supré et al. 2011). Moreover, CNS are known to possess important virulence factors to evade the host's imune system and to produce biofilms, leading to persistent intramammary infection (Thorberg et al. 2009, Supré et al. 2011).
In addition, CPS were also detected, including seven $S$. aureus that is considered the main etiologic agent of cow mastitis worldwide (Freitas et al. 2018). Curiously, S. aureus frequency observed here was lower than in other Brazilian studies with this disease in cow herds (Krewer et al. 2014, Valmorbidaet al. 2017, Freitas et al. 2018, Lavor et al. 2019). This epidemiological feature is probably associated with the differences in the cows microbiotas from dairy farms located in different geographic regions. Also S. pseudintermedius was identified in one sample. It is a commensal bacteria of skin and mucous membrane, frequently isolated from companion animals (Smith et al. 2020). Despite being a rare scientific finding, cow mastitis by this bacterial species was already reported (Pilla et al. 2013). The close contact among pets, humans and farm animals may have contributed to the contamination of the herds.

Noteworthy, other two Gram-positive bacterial genera were detected: Streptococcus and Enterococcus. Streptococcus spp. is another important genus associated with clinical mastitis. The two isolates identified as $S$. uberis by MALDI-TOF MS deserve special attention, once this species is an environmental pathogen responsible for a significant proportion of mastitis cases and associated with the lack of hygiene in the dairy farms (Valmorbida et al. 2017). This pathogen can persist in the udder and cause a chronic infection in the mammary gland. Thus, a contagious route of spread of Streptococcus uberis is also likely through the milking machine (Lopez-Benavides et al. 2007, Leelahapongsathon et al. 2020). In the same way, enterococci are environmental causative agents of cow mastitis (Różańska et al. 2019). They are commensals of the gastrointestinal tract of different animal species and the feces can contaminate milk samples (Chajęcka-Wierzchowska et al. 2020). Specifically, Enterococcus faecalis has been detected in bovine mastitis worldwide, from $0.2 \%$ to more than $60 \%$ (Tenhagen et al. 2006, Petersson-Wolfe et al. 2008, Nam et al. 2010, Hamzah \& Kadim 2018, Yang et al. 2018, Różańska et al. 2019).

Also, some Gram-negative bacterial were isolated, including Klebsiella variicola and Serratia marcescens. Reports of K. variicola isolation from cow mastitis are scarce, but this pathogen has been under-reported due to the inefficiency of traditional microbiological methods to discriminate it from Klebsiella pneumoniae (Podder et al. 2014). Serratia spp. is also not frequent in mastitis cases, but it is a ubiquitous bacteria already associated with long-lasting clinical and subclinical mastitis (Schukken et al. 2012). Specifically, S. marcescens outbreaks were already detected in dairy farms with significant economic impacts (Friman et al. 2019). These two bacterial species are also human pathogens and associated with nosocomial outbreaks (Rodríguez-Medina et al. 2019, Silva et al. 2021).

The identification of bacterial resistance is necessary to choose the appropriate antimicrobial treatment for cows (Lavor et al. 2019). Importantly, it was observed a high frequency of bacterial resistance to penicillin, tetracycline, amoxicillin, ampicillin and sulfamethoxazole/trimethoprim in this study (46.3\%, 39\%, 36.6\%, 34.1\% and 31.7\%, respectively). Antimicrobial resistance is not a recent phenomenon, but it has progressively increased in the last decades due to an abusive use in veterinary and human medicine (Valmorbida et al. 2017). The high frequency of resistance to some of these antimicrobials were expected, since they were frequently used in veterinary practice in recent years (Dorneles et al. 2018). 
Staphylococci isolates presented a wide range of resistance (from 0 to 58.7\%). Studies carried out in different Brazilian regions have already shown that Staphylococcus spp. isolated from dairy farms present high levels of resistance to trimethoprim (Freitas et al. 2018), sulfamethoxazole/ trimethoprim (Valmorbida et al. 2017, Dorneles et al. 2018), tetracycline (Martini et al. 2017, Valmorbida et al. 2017, Dorneles et al. 2018, Mesquita et al. 2019) and penicillin (Machado et al. 2008, Silva et al. 2012, Martini et al. 2017, Dorneles et al. 2018, Freitas et al. 2018, Mesquita et al. 2019). Additionally, six isolates were MDR, including five $S$. chromogenes and one $S$. aureus. CNS isolates from cow mastitis, such as $S$. chromogenes, were already reported to develop resistance to antimicrobials drugs more frequently than S. aureus (Taponen \& Pyörälä 2009). MDR in the dairy supply chain has also been previously reported and it is a very concerning health problem (Machado et al. 2008, Silva et al. 2012, Valmorbida et al. 2017, Dorneles et al. 2018, Freitas et al. 2018). There is a true risk for the transmission of these bacteria to animals and humans through the consumption of feed and food (Valmorbida et al. 2017, Dorneles et al. 2018). In addition, E. faecalis isolated here was resistant to the half of the tested antimicrobials. Although information about $E$. faecalis recovered from bovine mastitis in Brazil is rare, this bacterial species has frequently a very high antimicrobial resistance profile (Yang et al. 2018, Gao et al. 2019, Różańska et al. 2019). So it is a potential risk to contaminate milk products and human consumers (Różańska et al. 2019). On contrast, thirteen Gram-positive isolates (31.7\%) were susceptible to all evaluated antimicrobials, including two S. uberis. These results disagree to previous studies with Brazilian herds that demonstrated streptococci with high levels of resistance (Oliveira et al. 2011, Valmorbida et al. 2017), requiring longer periods of treatments (Kibebew 2017).

$K$. variicola strains presented resistance to penicillin, amoxicillin and ampicillin as expected, since Klebsiella species have a mechanism to resist these antimicrobial based on chromosomal $\beta$-lactamases LEN (Rodríguez-Medina et al. 2019 ). The two isolates also presented susceptibility to the other antimicrobials as previously described (Podder et al. 2014). The unique $S$. marcescens isolated in this study was resistant to a high number of antimicrobials. S. marcescens is difficult to treat since it is intrinsically resistant to many antimicrobials, due to multi-drug efflux pump(s) (Friman et al. 2019). Even using the correct treatment, the bacteriological elimination rate is low, with poor responses to antimicrobial therapy (Pinzón-Sánchez \& Ruegg 2011).

Bacterial resistance to fluoroquinolones, aminoglycosides and third generation cephalosporin was not observed, despite these antimicrobials have been widely used for the treatment of bovine mastitis and other cattle diseases in Brazil (Tomazi \& Dos Santos 2020). Low resistance to these classes have already been observed in dairy herds in Rio Grande do Sul (Girardini et al. 2016, Haubert et al. 2017, Lavor et al. 2019), showing that regional differences in the use of these antimicrobials could produce different selection pressures on bacterial populations. These results highlight the importance of the regional characterization of circulating strains (Valmorbida et al. 2017).

Importantly, it was not possible to obtain a high number of bacterial isolates to achieve more definitive data about the main bacterial species as well as their resistance to the currently used antimicrobials. Also some important clinical data from the animals were missed since the samples were obtained by convenience in low-income communities in the region. However, the findings presented here are very important to demonstrate the main bacterial species associated with bovine mastitis in a very important milk-producing region in South Brazil. More studies are necessary to reinforce these results in dairy farms in the different dairy regions to have a more complete scenario about mastitis in Brazil.

Finally, antimicrobials frequently used in veterinary medicine are still legally purchased in Brazil without veterinary prescription, which could further facilitate the excessive and incorrect use of antimicrobials in dairy herds, favoring persistent infections and antimicrobial resistance (Martini et al. 2017, Tomazi \& Dos Santos 2020). In addition to this serious animal and public health problem, it can result in direct financial losses to dairy farmers due to medicines costs and milk waste during treatment (Lavor et al. 2019). The complete and accurate microorganism identification in bovine mastitis is essential to determine the reservoirs and sources of infection, and to adopt the appropriate hygienic measures (Dorneles et al. 2018). Therefore, good management practices combined with the rational use of antimicrobials are of paramount importance to avoid emerging bacterial resistance in human dairy products.

\section{CONCLUSIONS}

Staphylococcus spp., grouped as CNS, was the predominant genus identified as the cause of bovine mastitis.

A high resistance rates to $\beta$-lactamics and tetracyclines was observed among the bacteria isolates, these antimicrobials classes are widely prescribed as a treatment of mastitis in dairy farms in the Northeast region of Rio Grande do Sul, Brazil.

These findings point out the need of a judicious analysis about the use of antimicrobials in small dairy herds, counting whenever possible with the correct identification of the pathogen and evaluation of the in vitro susceptibility profile.

Acknowledgements.- This study was supported by the Brazilian agencies "Conselho Nacional de Desenvolvimento Científico e Tecnológico" (CNPq) and "Coordenação de Aperfeiçoamento de Pessoal de Nível Superior" (CAPES), Brazil, FinanceCode 001.

Conflict of interest statement.- The authors have no competing interests.

\section{REFERENCES}

Barkema H.W., Schukken Y.H., \& Zadoks R.N. 2006. Invited review: The role of cow, pathogen, and treatment regimen in the therapeutic success of bovine Staphylococcus aureus mastitis. J. Dairy Sci. 89(6):1877-1895. <https:// dx.doi.org/10.3168/jds.S0022-0302(06)72256-1> <PMid:16702252>

Bauer A.W., Kirby W.M.M., Sherris J.C. \& Turck M. 1966. Antibiotic susceptibility testing by a standardized single disk method. Am. J. Clin. Pathol. 45(4):493496. <https://dx.doi.org/10.1093/ajcp/45.4_ts.493> <PMid:5325707>

Blaiotta G., Fusco V., Ercolini D., Pepe O. \& Coppola S. 2010. Diversity of Staphylococcus species strains based on partial kat (catalase) gene sequences and design of a PCR-restriction fragment length polymorphism assay for identification and differentiation of coagulase-positive species (S. aureus, S. delphini, S. hyicus, $S$. intermedius, S. pseudintermedius, and $S$. schleiferi subsp. coagulans). J. Clin. Microbiol. 48(1):192-201. <https:// dx.doi.org/10.1128/JCM.00542-09><PMid:19889901> 
Braga P.A.C., Gonçalves J.L., Barreiro J.R., Ferreira C.R., Tomazi T., Eberlin M.N. \& Santos M.V. 2018. Rapid identification of bovine mastitis pathogens by MALDI-TOF Mass Spectrometry. Pesq. Vet. Bras. 38(4):586-594. <https:// dx.doi.org/10.1590/1678-5150-PVB-4821>

Chajęcka-Wierzchowska W., Zadernowska A. \& García-Solache M. 2020. Readyto-eat dairy products as a source of multidrug-resistant Enterococcus strains: phenotypic and genotypic characteristics. J. Dairy Sci. 103(5):4068-4077. <https://dx.doi.org/10.3168/jds.2019-17395><PMid:32197843>

CLSI 2020. Performance Standards for Antimicrobial Susceptibility Testing. CLSI supplement M100, Clinical and Laboratory Standards Institute, Wayne, PA.

Dorneles E.M.S., Fonseca M.D.A.M., Abreu J.A.P., Lage A.P., Brito M.A.V.P., Pereira C.R., Brandão H.M., Guimarães A.S. \& Heinemann M.B. 2018. Genetic diversity and antimicrobial resistance in Staphylococcus aureus and coagulase-negative Staphylococcus isolates from bovine mastitis in Minas Gerais, Brazil. MicrobiologyOpen 8(5):e00736. <https://dx.doi. org/10.1002/mbo3.736><PMid:30298561>

Duarte V.S., Treu L., Sartori C., Dias R.S., Paes I.S., Vieira M.S., Santana G.R., Marcondes M.I., Giacomini A., Corich V., Corich V., Campanaro S., Silva C.C. \& Paula S.0. 2020. Milk microbial composition of Brazilian dairy cows entering the dry period and genomic comparison between Staphylococcus aureus strains susceptible to the bacteriophage vB_SauM-UFV_DC4. Sci. Rep. 10(1):5520. <https://dx.doi.org/10.1038/s41598-020-62499-6> <PMid:32218514>

Freitas C.H., Mendes J.F., Vilarreal P.V., Santos P.R., Gonçalves C.L., Gonzales H.L. \& Nascente O.S. 2018. Identification and antimicrobial susceptibility profile of bacteria causing bovine mastitis from dairy farms in Pelotas, Rio Grande do Sul. Braz.J. Biol.78(4):661-666. <https://dx.doi.org/10.1590/1519-6984.170727>

Friman M.J., Eklund M.H., Pitkälä A.H., Rajala-Schultz P.J. \& Rantala M.H.J. 2019. Description of two Serratia marcescens associated mastitis outbreaks in Finnish dairy farms and a review of literature. Acta Vet. Scand. 61:54. <https://dx.doi.org/10.1186/s13028-019-0488-7> <PMid:31727124>

Gao X., Fan C., Zhang Z., Li S., Xu C., Zhao Y., Han L., Zhang D. \& Liu M. 2019. Enterococcal isolates from bovine subclinical and clinical mastitis: antimicrobial resistance and integron-gene cassette distribution. Microb. Pathog. 129:82-87. <https://dx.doi.org/10.1016/j.micpath.2019.01.031> $<$ PMid:30682528>

Girardini L.K., Paim D.S., Ausani T.C., Lopes G.V., Pellegrini D.C.P., Brito M.A.V.P. \& Cardoso M. 2016. Antimicrobial resistance profiles of Staphylococcus aureus clusters on small dairy farms in southern Brazil. Pesq. Vet. Bras. 36(10):951-956. <https://dx.doi.org/10.1590/S0100-736X2016001000006>

Hamzah A.M. \& Kadim H.K. 2018. Isolation and identification of Enterococcus faecalis from cow milk samples and vaginal swab from human. J. Entomol. Zool. Stud. 6(1):218-222.

Haubert L., Kroning I.S., Iglesias M.A. \& Silva W.P. 2017. First report of the Staphylococcus aureus isolated from subclinical bovine mastitis in the South of Brazil harboring resistance gene $\mathrm{dfrG}$ and transposon family Tn916-1545. Microb. Pathog. 113:242-247.<https://dx.doi.org/10.1016/j. micpath.2017.10.022><PMid:29051059>

Holko I., Tančin V., Vršková M. \& Tvarožková K. 2019. Prevalence and antimicrobial susceptibility of udder pathogens isolated from dairy cows in Slovakia. J. Dairy Res. 86(4):436-439. <https://dx.doi.org/10.1017/ S0022029919000694><PMid:31727191>

Kibebew K. 2017. Bovine mastitis: a review of causes and epidemiological point of view. J. Biol. Agric. Health 7(2):1-14.

Kim S.-J., Moon D.C., Park S.-C., Kang H.Y., Na S.H. \& Lim S.-K. 2019. Antimicrobial resistance and genetic characterization of coagulase-negative staphylococci from bovine mastitis milk samples in Korea. J. Dairy Sci. 102(12):1143911448. <https://dx.doi.org/10.3168/jds.2019-17028><PMid:31548061>

Krewer C.C., Amanso E.S., Gouveia G.V., Souza R.L., Costa M.M. \& Mota R.A. 2014. Resistance to antimicrobials and biofilm formation in Staphylococcus spp. isolated from bovine mastitis in the Northeast of Brazil. Trop. Anim. Health Prod. 47(3):511-518. <https://dx.doi.org/10.1007/s11250-0140752-9><PMid:25547807>
Lavor U.L., Guimarães F.F., Salina A., Mioni M.S.R. \& Langoni H. 2019. Bacterial identification, somatic cell count, antimicrobial profile and toxigenic Staphylococcus strains search from mastitic cow milk samples on small farms properties. Pesq. Vet. Bras. 39(9):715-722. <https://dx.doi. org/10.1590/1678-5150-PVB-5523>

Leelahapongsathon K., Schukken Y.H., Srithanasuwan A. \& Suriyasathaporn W. 2020. Molecular epidemiology of Streptococcus uberis intramammary infections: persistent and transient patterns of infection in a dairy herd. J. Dairy Sci. 103(4):3565-3576. <https://dx.doi.org/10.3168/jds.2019-17281>

Lopez-Benavides M.G., Williamson J.H., Pullinger G.D., Lacy-Hulbert S.J., Cursons R.T. \& Leigh J.A. 2007. Field observations on the variation of Streptococcus uberis populations in a pasture-based dairy farm. J. Dairy Sci. 90(12):5558-5566. <https://dx.doi.org/10.3168/jds.2007-0194> <PMid:18024747>

Machado T.R.O., Correa M.G. \& Marin J.M. 2008. Antimicrobial susceptibility of coagulase-negative Staphylococci isolated from mastitic cattle in Brazil. Arq. Bras. Med. Vet. Zootec. 60(1):278-282.<https://dx.doi.org/10.1590/ S0102-09352008000100041>

Martini C.L., Lange C.C., Brito M.A., Ribeiro J.B., Mendonça L.C. \& Vaz E.K. 2017. Characterisation of penicillin and tetracycline resistance in Staphylococcus aureus isolated from bovine milk samples in Minas Gerais, Brazil. J. Dairy Res. 84(02):202-205. <https://dx.doi.org/10.1017/S0022029917000061> $<$ PMid:28290267>

Mesquita A.A., Rocha C.M.B.M., Bruhn F.R.P., Custódio D.A.C., Braz M.S., Pinto S.M., Silva D.B. \& Costa G.M. 2019. Staphylococcus aureus and Streptococcus agalactiae: prevalence, resistance to antimicrobials, and their relationship with the milk quality of dairy cattle herds in Minas Gerais state, Brazil. Pesq. Vet. Bras. 39(5):308-316.<https://dx.doi.org/10.1590/1678-5150-PVB-5821>

Nam H.M., Lim S.K., Moon J.S., Kang H.M., Kim J.M., Jang K.C., Kim J.M., Kang M.I., Joo Y.S. \& Jung S.C. 2010. Antimicrobial resistance of enterococci isolated from mastitic bovinemilk samples in Korea. Zoonoses Publ. Health 57(7/8):e59-e64. <https://dx.doi.org/10.1111/j.1863-2378.2009.01307. $\mathrm{x}><$ PMid:20042062>

NMC 2004. Microbiological Procedures for the Diagnosis of Bovine Udder Infection and Determination of Milk Quality. 4th ed. National Mastitis Council, Verona, p.1-30.

Oliveira C.M.C., Sousa M.G.S., Silva N.S., Mendonça C.L., Silveira J.A.S., Oaigen R.P., Andrade S.J.T. \& Barbosa J.D. 2011. Prevalence and etiology of bovine mastitis in the dairy region of Rondon do Pará, state of Pará. Pesq. Vet. Bras. 31(2):104-110.<https://dx.doi.org/10.1590/S0100-736X2011000200002>

Petersson-Wolfe C.S., Adams S., Wolf S.L. \& Hogan J.S. 2008. Genomic typing of enterococci isolated from bovine mammary glands and environmental sources. J. Dairy Sci. 91(2):615-619. <https://dx.doi.org/10.3168/jds.2007-0253>

Pilla R., Bonura C., Malvisi M., Snel G.G.M. \& Piccinini R. 2013. Methicillinresistant Staphylococcus pseudintermedius as causative agent of dairy cow mastitis. Vet. Rec. 173(1):19. <https://dx.doi.org/10.1136/vr.101485> $<$ PMid:23723102>

Pinzón-Sánchez C. \& Ruegg P.L. 2011. Risk factors associated with short-term post-treatment outcomes of clinical mastitis. J. Dairy Sci. 94(7):3397-3410. <https://dx.doi.org/10.3168/jds.2010-3925><PMid:21700025>

Podder M.P., Rogers L., Daley P.K., Keefe G.P., Whitney H.G. \& Tahlan K. 2014. Klebsiella species associated with bovine mastitis in Newfoundland. PloS One 9(9):e106518. <https://dx.doi.org/10.1371/journal.pone.0106518> $<$ PMid:25180510>

Rodríguez-Medina N., Barrios-Camacho H., Duran-Bedolla J. \& Garza-Ramos U. 2019. Klebsiella variicola: an emerging pathogen in humans. Emerg. Microbes Infect. 8(1):973-988. <https://dx.doi.org/10.1080/22221751. 2019.1634981><PMid:31259664>

Różańska H., Lewtak-Piłat A., Kubajka M. \& Weiner M. 2019. Occurrence of enterococci in mastitic cow's milk and their antimicrobial resistance. J. Vet. Res. 63(1):93-97. <https://dx.doi.org/10.2478/jvetres-2019-0014> $<$ PMid:30989140> 
Ruegg P.L. 2017. A 100-Year Review: Mastitis detection, management, and prevention. J. Dairy Sci. 100(12):10381-10397. <https://dx.doi.org/10.3168/ jds.2017-13023> <PMid:29153171>

Schmidt T., Kock M.M. \& Ehlers M.M. 2015. Diversity and antimicrobial susceptibility profiling of staphylococci isolated from bovine mastitis cases and close human contacts. J. Dairy Sci. 98(9):6256-6269. <https:// dx.doi.org/10.3168/jds.2015-9715><PMid:26188567>

Schukken Y., Chuff M., Moroni P., Gurjar A., Santisteban C., Welcome F. \& Zadoks R. 2012. The "other" gram-negative bacteria in mastitis. Vet. Clin. N. Am., Food Anim. Pract. 28(2):239-256. <https://dx.doi.org/10.1016/j. cvfa.2012.04.001 ><PMid:22664206>

Silva E.R., Pereira A.M.G., Moraes W.S., Santoro K.R. \& Silva T.R.M. 2012. In vitro antimicrobial susceptibility of "Staphylococcus aureus" isolated from bovine subclinical mastitis. Revta Bras. Saúde Prod. Anim.13(3):701-711. <https://dx.doi.org/10.1590/S1519-99402012000300010>

Silva K.E., Rossato L., Jorge S., Oliveira N.R., Kremer F.S., Campos V.F., Pinto L.S., Dellagostin 0.A. \& Simionatto S. 2021. Three challenging cases ofinfections by multidrug-resistant Serratia marcescens in patients admitted tointensive care units. Braz. J. Microbiol. 52(3):1341-1345. <https://dx.doi.org/10.1007/ s42770-021-00477-4> <PMid:33829377>

Smith J.T., Amador S., McGonagle C.J., Needle D., Gibson R. \& Andam C.P. 2020. Population genomics of Staphylococcus pseudintermedius in companion animals in the United States. Commun. Biol. 3:282. <https://dx.doi. org/10.1038/s42003-020-1009-y>

Supré K., Haesebrouck F., Zadoks R.N., Vaneechoutte M., Piepers S. \& De Vliegher S. 2011. Some coagulase-negative Staphylococcus species affect udder health more than others. J. Dairy Sci. 94(5):2329-2340. <https:// dx.doi.org/10.3168/jds.2010-3741><PMid:21524522>

Sztachańska M., Barański W., Janowski T., Pogorzelska J. \& Zduńczyk S. 2016. Prevalence and etiological agents of subclinical mastitis at the end of lactation in nine dairy herds in North-East Poland. Pol. J. Vet. Sci. 19(1):119124. <https://dx.doi.org/10.1515/pjvs-2016-0015> <PMid:27096795>

Taponen S. \& Pyörälä S. 2009. Coagulase-negative staphylococci as cause of bovine mastitis- not so different from Staphylococcus aureus? Vet. Microbiol. 134(1/2):29-36. <https://dx.doi.org/10.1016/j.vetmic.2008.09.011> $<$ PMid:18977615>

Tenhagen B.-A., Köster G., Wallmann J. \& Heuwieser W. 2006. Prevalence of mastitis pathogens and their resistance against antimicrobial agents in dairy cows in Brandenburg, Germany. J. Dairy Sci. 89(7):2542-2551. <https:// dx.doi.org/10.3168/jds.S0022-0302(06)72330-X><PMid:16772573>
Thorberg B.-M., Danielsson-Tham M.-L., Emanuelson U. \& Waller K.P. 2009. Bovine subclinical mastitis caused by different types of coagulase-negative staphylococci. J. Dairy Sci. 92(10):4962-4970. <https://dx.doi.org/10.3168/ jds.2009-2184><PMid:19762813>

Tomazi T. \& Dos Santos M.V. 2020. Antimicrobial use for treatment of clinical mastitis in dairy herds from Brazil and its association with herd-level descriptors. Prev. Vet. Med. 176:104937. <https://dx.doi.org/10.1016/j. prevetmed.2020.104937><PMid:32126401>

Tomazi T., Goncalves J.L., Barreiro J.R., Braga P.A.C., Silva L.F.P., Eberlin M.N. \& Santos M.V. 2014. Identification of coagulase-negative staphylococci from bovine intramammary infection by matrix-assisted laser desorption ionization-time of flight mass spectrometry. J. Clin. Microbiol. 52(5):16581663. <https://dx.doi.org/10.1128/JCM.03032-13><PMid:24622096>

Vakkamäki J.,Taponen S., Heikkilä A.-M. \& Pyörälä S. 2017. Bacteriological etiology and treatment of mastitis in Finnish dairy herds. Acta Vet. Scand. 59:33. <https://dx.doi.org/10.1186/s13028-017-0301-4>

Valmorbida M.K., Carneiro D.C.S., Prior K.C., Griebeler E., Troncarelli M.Z. \& Dezen D. 2017. Etiology and in vitro antimicrobial susceptibility profile of strains isolated from bovine mastitis in dairy herds from the midwest region of Santa Catarina state, Brazil. Acta Vet. Bras. 11:219-225. <https:// dx.doi.org/10.21708/avb.2017.11.4.7266>

Vanderhaeghen W., Piepers S., Leroy F., Van Coillie E., Haesebrouck F. \& De Vliegher S. 2014. Effect, persistence, and virulence of coagulase-negative Staphylococcus species associated with ruminant udder health. J. Dairy Sci. 97(9):5275-5293. <https://dx.doi.org/10.3168/jds.2013-7775> <PMid:24952781>

Verbeke J., Piepers S., Supré K. \& De Vliegher S. 2014. Pathogen-specific incidence rate of clinical mastitis in Flemish dairy herds, severity, and association with herd hygiene. J. Dairy Sci. 97(11):6926-6934. <https:// dx.doi.org/10.3168/jds.2014-8173><PMid:25218745>

Yang F., Zhang S., Shang X., Wang X., Yan Z., Li H. \& Li J. 2018. Short communication: antimicrobial resistance and virulence genes of Enterococcus faecalis isolated from subclinical bovine mastitis cases in China. J. Dairy Sci. 102(1):140144. <https://dx.doi.org/10.3168/jds.2018-14576><PMid:30415850>

Zhang S., Piepers S., Shan R., Cai L., Mao S., Zou J., Ali T., De Vliegher S. \& Han B. 2018. Phenotypic and genotypic characterization of antimicrobial resistance profiles in Streptococcus dysgalactiae isolated from bovine clinical mastitis in 5 provinces of China. J. Dairy Sci. 101(4):3344-3355.<https:// dx.doi.org/10.3168/jds.2017-14031><PMid:29397161> 